\title{
Assessment of Concentrations of Heavy Metals and Phthalates in Two Urban Rivers of the Northeast of Puerto Rico
}

\author{
Ana I Ortiz-Colón ${ }^{1,2,3}$, Luis E Piñero-Santiago ${ }^{4}$, Nilsa M Rivera ${ }^{1,2,3}$ and María A Sosa ${ }^{1,2,3^{*}}$ \\ ${ }^{1}$ Department of Anatomy and Neurobiology, School of Medicine, Medical Science Campus, University of Puerto Rico, San Juan, Puerto Rico, 00936 USA \\ ${ }^{2}$ Institute of Neurobiology, Medical Sciences Campus, University of Puerto Rico, San Juan, Puerto Rico, 00901 USA \\ ${ }^{3}$ Puerto Rico Center for Environmental Neuroscience, Medical Sciences Campus, San Juan, Puerto Rico, 00936 USA \\ ${ }^{4}$ Department of Chemistry, Humacao Campus, University of Puerto Rico, Humacao, Puerto Rico, 00792 USA
}

\begin{abstract}
Urbanization adjacent to rivers has increased in recent years and is considered a source of environmental contamination. The resulting increase in number of urban rivers in highly populated areas, such as the Caribbean island of Puerto Rico, has led to the appearance of synthetic as well as naturally occurring chemicals not previously observed nor regularly monitored in freshwater habitats. Some of these chemicals, such as heavy metals and plasticizers, have been shown to affect endocrine, respiratory, and nervous system function in animals and humans, even at relatively low concentrations. The purpose of this study was to measure concentrations of such emergent contaminants on rivers of urbanized areas on the northeast of Puerto Rico, as one element in the assessment of the impact of urbanism on water quality in these communities. To accomplish this, we used Inductively Coupled Plasma and Gas Chromatography Mass Spectrometry to measure amounts of heavy metals and phthalates, respectively, in superficial water of three rivers of Puerto Rico: Mameyes (non-urban), Río Piedras (urban river without a dam), and La Plata (urban river with a dam). The urban rivers had significantly higher concentrations of heavy metals arsenic, barium, cadmium, manganese, and antimony, when compared with the reference nonurban river. Manganese was the only metal found in concentrations higher than limits established by the EPA for drinking water. Of eight phthalates amenable to measurement with the chosen protocol and instrumentation, only dibutyl phthalate was detected, only in the La Plata river, and at concentrations ranging from 3 to 8 parts-per-billion. These findings suggest that urbanism close to rivers of Puerto Rico is likely having an impact on water quality and thus further study to identify the potential sources, as well as the inclusion of these emergent contaminants on the list of chemicals regularly monitored by government agencies is justified.
\end{abstract}

Keywords: Urbanism; Emergent contaminants; Water pollution; Plasticizers; Consumer products solvents

\section{Introduction}

The continuous increase of the population and social, economic, and infrastructure development experienced in Latin American countries and the Caribbean in recent decades has triggered a rapid urban growth, where many inhabitants have migrated from rural areas to concentrate in urban zones. The urbanization process in these countries has reached a level where their urban region is considered as one of the most urbanized worldwide, along with North America and Europe. In 1950, the urban population in Latin America and the Caribbean was $41.4 \%$, increasing by 1995 to $73.4 \%$, and around $79 \%$ by 2010. It is estimated that by the year 2030 the urban population in these countries will be $83.2 \%$ [1]. In the next 30 years, a similar pattern of increased urbanism is expected in other continents like Asia and Africa [2].

Puerto Rico, a self-governing dependent territory of the United States (US) with an area of $8,870 \mathrm{~km}^{2}$, is considered one of the oldest urban regions in the tropics. During the decade of the 1940s, the Puerto Rican economy was based mostly on agriculture. Throughout the 1960s the island's economy initiated a transition from agriculture towards industrialization, a period during which people started moving from rural to urban areas. In 2014 the island's population was estimated at 3.548 million inhabitants, with an average density of 400 inhabitants/ $\mathrm{km}^{2}$, among the world's highest. This corresponds to position \#24, according to the World Bank [3], amongst a list of the 214 sovereign states and self-governing dependent territories of the world today, and position \#3, according to the US Census, within the states and territories of the United States [4].

The urban growth of Puerto Rico and Latin America has been characterized by its ample expansion around metropolitan centers. In Puerto Rico, urban growth is more evident near the metropolitan area of the municipalities of San Juan-Bayamón-Carolina [5], while in Latin
America it is more prevalent in the cities of Panamá and Guatemala, San José in Costa Rica, Santiago in Chile, Lima in Perú, and Buenos Aires in Argentina [6].

The urbanistic process involves the progressive conversion of natural ecological systems to urban ones [7]. This process often is considered a threat to the surrounding ecosystems [8] because of the alteration of the atmospheric composition, impact on the hydrology of rivers, the geomorphology of beds of water bodies, and accumulation of contaminants in the ground cover, eventually also reaching water bodies. In addition, urbanism is associated with various sources of contamination such as industrial waste, fluids from heating and refrigeration systems, transport systems, water waste, collection and disposal of solids, industrial plant waste and sewer runoff, among others.

The impact of urbanism on rivers is due primarily to changes on the routes of their tributaries and channels and its bank walls to make them fit to the layout of housing and businesses. These changes increase land impermeable areas that prevent normal ground percolation of rain water, and result in fast washing towards the rivers of pollutants generated by humans living in these urban areas, including solvents, dyes, household products, fluids and particulates from automobiles,

*Corresponding author: María A. Sosa, $\mathrm{PhD}$, Department of Anatomy and Neurobiology, Office A543 UPR, School of Medicine, PO Box 365067, San Juan, PR 00936-5067, USA, Tel: 787-758-2525 extn. 1514/1500; Fax: 787-7670788; E-mail: maria.sosa@upr.edu

Received March 01, 2016; Accepted March 16, 2016; Published March 24, 2016

Citation: Ortiz-Colón Al, Piñero-Santiago LE, Rivera NM, Sosa MA (2016) Assessment of Concentrations of Heavy Metals and Phthalates in Two Urban Rivers of the Northeast of Puerto Rico. J Environ Anal Toxicol 6: 353. doi:10.4172/2161 0525.1000353

Copyright: $\odot 2016$ Ortiz-Colón Al, et al. This is an open-access article distributed under the terms of the Creative Commons Attribution License, which permits unrestricted use, distribution, and reproduction in any medium, provided the original author and source are credited. 
fertilizers and pesticides used in parks, gardens and green areas, etc. [7]. Studies have been carried out in various countries regarding contamination of rivers as a result of urbanism and associated anthropogenic activities.

Traces of manganese $(\mathrm{Mn})$, iron $(\mathrm{Fe})$, cobalt $(\mathrm{Co})$, bromine $(\mathrm{Br})$, copper $(\mathrm{Cu})$, zinc $(\mathrm{Zn})$, lead $(\mathrm{Pb})$, cadmium $(\mathrm{Cd})$, chromium $(\mathrm{Cr})$, nickel $(\mathrm{Ni})$, and arsenic (As) have been identified in various freshwater bodies throughout the world [1,9-31]. In Canada and the states of Washington and Oregon of the US, the Columbia River, the largest river in the Pacific Northwest region of North America, has been contaminated with heavy metals $\mathrm{Cu}, \mathrm{Cd}$, and $\mathrm{Zn}$ from metallurgic industries, discharge from municipalities, and mines [1]. Similar urban contamination with metals has been reported in the Marcal River of Hungary, rivers of Southeast Asia, west Finland, southeast Brazil, Serbia and central Nigeria, as well as in tributaries of the Nile River in Egypt. The metals most commonly found in these rivers have been $\mathrm{Cr}$, $\mathrm{Zn}, \mathrm{Cd}$ and $\mathrm{Cu}$ [9-17]. Heavy metals in water pose a worrisome health threat because they tend to be taken up by fish $[10,29,32-38]$ and other animals that are used as food sources for humans, such as mollusks and crustaceans $[19,39-46]$.

The Yangtze river of China, the third longest of the world, is considered an urban river because the activity of 8 million inhabitants is concentrated on its river banks. In the past 10 years it has been characterized by the presence of high concentrations of polychlorinated biphenyls (PCBs) [23], organic contaminants coming from plastics. PCBs have been shown to affect several biological processes such as chondrocyte death, cell death involving mechanisms of apoptosis, necrosis and oxidative stress, and have also been associated with impairment of intellectual ability during early human development and neurobehavioral alterations in newborns [47-52].

A recent (2014) review article by Cousins and colleagues [53] summarizes evidence compiled between 1973 and 2008 on the presence of various phthalates, other components of plastics, including diethyl phthalate (DEP), dibutyl phthalate (DBuP), di-(2-ethylhexyl) phthalate (DEHP), and benzylbutyl phthalate (BzBuP), in outdoor and indoor air in different countries in North America, Europe and Asia. The origin of the majority of phthalates detected in these studies was found in domestic dust, an important source in highly urbanized areas that can easily contaminate air and water in close-by environments. Other studies looking at organic contaminants in bodies of water have identified phthalates as well. For example, a 2011 study of the Yangtze River, the main source of drinking water for the inhabitants of China and other Asian countries, found organic pesticides, aromatic hydrocarbons, polychlorinated biphenyls and phthalates, including DEP, DBuP, and DEHP [54], all linked to industries related with the manufacture of automobiles, fabrics, and electronics. Although thus far the concentrations of these contaminants in the Yangtze River are below the amounts allowed by government standards for surface water, concerns remain because the effects of prolonged exposure to low levels of these chemicals is not well characterized yet.

Research on the impact of urbanism and contamination in other parts of the world has shown that this phenomenon causes degradation of river ecosystems. However, studies of this type in tropical regions have been poorly documented $[8,55]$. Puerto Rico, as a small tropical island with urban development booming since the 1950s [5] is an ideal location to assess the impact of urbanism and contamination in various habitats or environments, including rivers, because a wide variety of ecosystems are found within relatively short distances. The resources from freshwater ecosystems directly contribute to the survival of the
Puerto Rican population and attract many people to settle on or near river banks. However, contamination of rivers due to increase in urbanization can negatively impact the health of humans and other animal species. This study seeks to measure amounts of metal and phthalates in three Puerto Rico Rivers surrounded by varying levels of urbanism to aid in evaluating how urbanism close to freshwater systems can affect water quality $[56,57]$.

\section{Materials and Methods}

\section{Sample collection}

Surface water samples were collected from two sampling sites at a non-urban or reference river, the Mameyes, and from three sampling sites in each of two urban rivers, the Río Piedras and Río La Plata, between May and November of 2013, which corresponds with the rainy season in Puerto Rico.

Water samples from each of the river's sampling points were taken in triplicate, as described in S.E Long (Technology Applications INC.), and in the Environmental Protection Agency's Methods 200.8 [58] and 200.2 [59], with few modifications. Clean one-liter amber plastic or glass bottles were used to collect water samples for analysis of metals and phthalates, respectively. Control sample bottles of each kind, containing ultra-pure water from the laboratory, were also taken to each sampling point, where they were handled in the same way as the river water sample bottles (including storage, transportation, and opening of the bottle on location, with the only difference that no river water is added).

Physicochemical properties of the water, such as temperature and $\mathrm{pH}$, were measured at each sampling point using an YSI Water Quality Meter (Model 63, YSI Incorporated, Yellow Springs, OH), while dissolved oxygen at each site was measured using YSI's ProODO Optical Digital Handheld Instrument.

\section{Processing and analysis of metals in the river water samples}

Amounts of various metals of interest, specifically silver (Ag), arsenic (As), barium (Ba), beryllium (Be), cadmium (Cd), chromium $(\mathrm{Cr})$, manganese $(\mathrm{Mg})$, nickel $(\mathrm{Ni})$, lead $(\mathrm{Pb})$, antimony $(\mathrm{Sb})$, selenium $(\mathrm{Se})$, thallium $(\mathrm{Tl})$ and zinc $(\mathrm{Zn})$, were analyzed in the surface water samples using Inductively Coupled Plasma - Mass Spectrometry (ELA 6100 model, Perkin Elmers, Waltham, MA) as described in US EPA Method 200.8 [59], with a few modifications in accordance with the instrument's specifications.

Briefly, volumes of $50 \mathrm{ml}$ of each water sample were treated with $1 \mathrm{ml}$ of nitric acid $\left(\mathrm{HNO}_{3} 70 \%\right.$, purified by re-distillation, $99.999+\%$ trace metals basis 1+1, Chemical and Chromatography Supplies, Inc., San Juan, PR) and $0.5 \mathrm{ml}$ of hydrochloric acid ( $\mathrm{HCl} 35-38 \% 1+1$, Fisher Scientific, Bridgewater, NJ), and digested and evaporated at $85^{\circ} \mathrm{C}$ for 4.5 hours. Volumes of $15-20 \mathrm{~mL}$ of each of these samples were then filtered to minimize the risk of any remaining solid residues from later on occluding the instrument. The filtration step is done after the digestion and evaporation process to make sure metals that may be adhered to solids in the sample are not lost during preparative processing. Distilled water was added to bring each sample to a final volume of $25 \mathrm{ml}$, they were mixed well, had $5 \mathrm{ml}$ removed, followed by a final addition of 30 $\mathrm{ml}$ of distilled water, reaching a final sample volume of $50 \mathrm{ml}$ (dilution factor of 1.25). Metal standards were obtained from ERA A Water Company (Colorado, USA). 
Citation: Ortiz-Colón Al, Piñero-Santiago LE, Rivera NM, Sosa MA (2016) Assessment of Concentrations of Heavy Metals and Phthalates in Two Urban Rivers of the Northeast of Puerto Rico. J Environ Anal Toxicol 6: 353. doi:10.4172/2161-0525.1000353

Page 3 of 10

\section{Processing and analysis of phthalates in the river water samples}

Preservation of the river water samples to be analyzed for phthalate content was secured by adding $3 \mathrm{ml}$ of nitric acid concentrate $(0.1$ $\mathrm{M} \mathrm{HNO}_{3}$ in $\mathrm{H}_{2} \mathrm{O}[0.1 \mathrm{~N}]$ eluent concentrate for ion chromatography [IC]; Chemical and Chromatography Supplies, Inc., San Juan, PR), followed by storage at room temperature. A solid phase extraction protocol was used prior to analysis, as described in Supelco Bulletin 910 (Sigma-Aldrich, St. Louis, MO) [57-61]. For this procedure a vacuum manifold (Sigma-Aldrich, St. Louis, MO) was used, fitted with Oasis Hydrophobic-Lipophilic Balance (HLB) glass cartridges (Part number: 186000116 Waters Technology, Caguas, PR), a vacuum pump, glass test tubes and glass Pasteur pipettes, using distilled water, ethyl acetate 99.999\% (VWR Radnor, Pennsylvania, USA) and methanol $99.9 \%$ (ACS spectrophotometer grade, Sigma Aldrich, St. Louis, MO), stored in glass bottles.

Glass cartridges were conditioned with $10 \mathrm{~mL}$ of a $25 \%$ solution of methanol in distilled water, and then rinsed with $10 \mathrm{~mL}$ of ultra-pure water. Flow through the cartridge was adjusted to $1 \mathrm{~mL} / \mathrm{min}$ to ensure the interaction of the particulate in the sample with the stationary phase. A volume of $300 \mathrm{~mL}$ of the sample was then gradually added, at this same flow rate. The solid phase of each cartridge was dried with a vacuum pump using nitrogen gas, and the components that bound to the stationary phase were extracted by adding $10 \mathrm{~mL}$ of ethyl acetate 99.999\%. The resulting eluates were collected in labeled tubes, with sequential fractions being pre-concentrated with nitrogen gas until reaching a volume of $1 \mathrm{~mL}$ each.
Analysis of samples for detection of phthalates was performed as described by Li and colleagues [62-64] using a Gas Chromatograph (GC) 2000 (Thermo Finnigan, San Diego, CA) coupled to a Mass Spectrometric Detector (Polaris Q, Thermo Electron, Austin, TX). A DB5MS capillary column of $30 \mathrm{~m}, 0.25 \mathrm{~mm}$ X $0.320 \mathrm{~mm}$ was employed for analyte separation. Instrument conditions were: initial temperature of $100^{\circ} \mathrm{C}$ with a rate of change of $5^{\circ} \mathrm{C} /$ minutes until reaching $250^{\circ} \mathrm{C}$, with a total run time of 30 minutes. Mass spectra were obtained at an electron impact potential of $70 \mathrm{eV}$ with a range of 30-500 amu.

Six phthalates, from a list of the eleven most commonly reported in the literature that were also commercially available, were chosen on the basis of the chemical properties that were most amenable to analysis using Gas Chromatography-Mass Spectrometry (GCMS), namely volatility, thermal stability, and capacity for ionization (Table 1, chosen phthalates shown in ${ }^{\star}$ ). Since it was thought likely that their concentrations in the river water samples could be near trace amounts, the minimum detection limit of the Polaris Q (MS) for phthalates was determined and found to be $0.01 \mathrm{mM}$. Initial screening or qualitative identification of the phthalates present in a river water sample was conducted using the instrument's full scan mode, followed by characterization with the single ion monitoring (SIM) mode to quantify the desired compounds.

\section{Statistical analysis}

Statistical comparisons amongst means of groups were performed by one-way ANOVA. When significant differences were detected through ANOVA, Tukey post hoc analysis was employed for individual

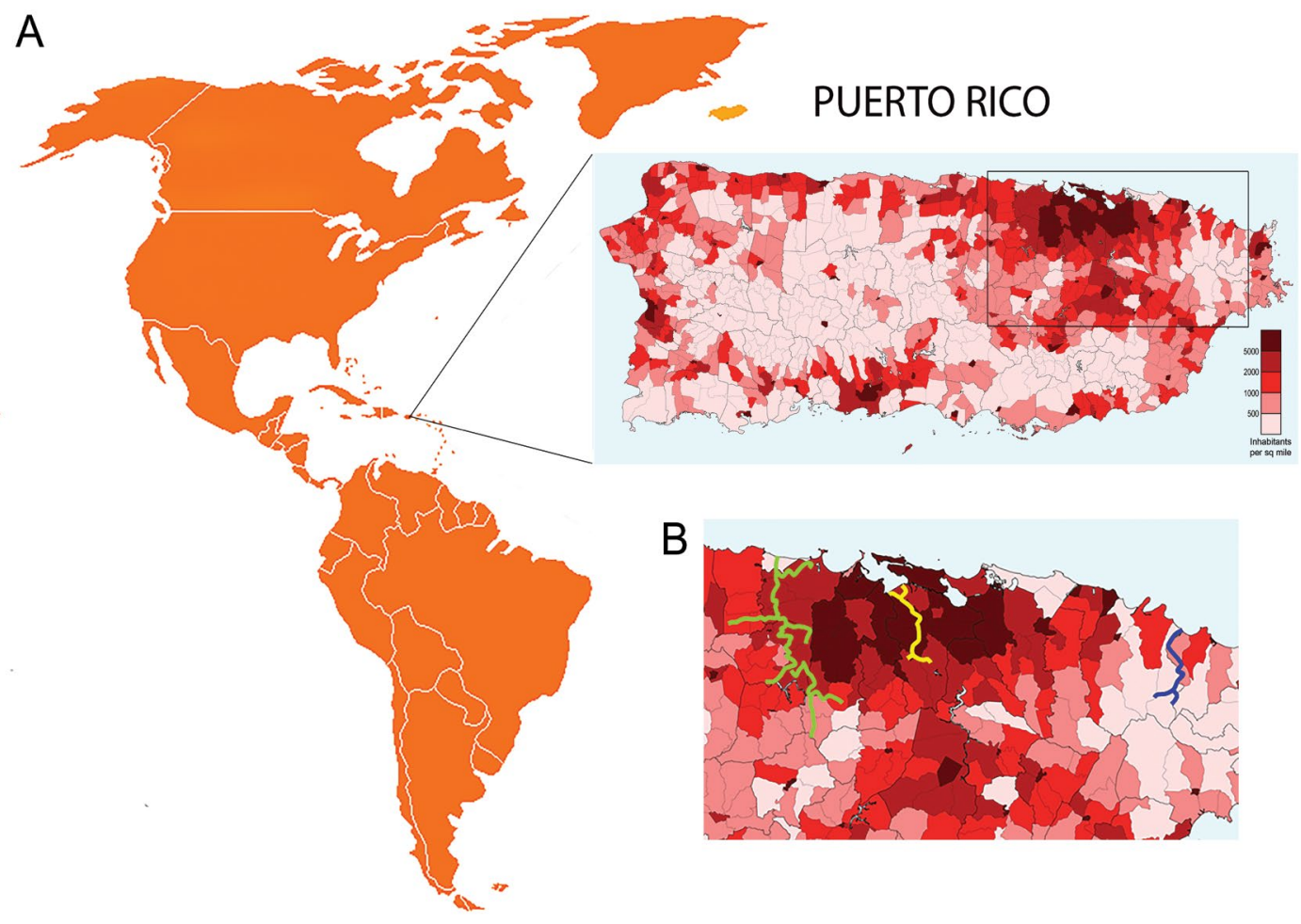

Figure 1: A. Map of Puerto Rico, showing location within the Greater Antilles archipelago. Enlarged map shows population density within regional subdivisions of municipalities. Color legend indicates number of inhabitants per square mile, based on the 2000 US Census data. The darker the color, the more densely populated the area is (map was created by Javier Rodríguez Galarza, copyright holder of the work under Creative Commons Attribution 3.0 License). B. Closer view of area shown in the rectangle on map A, showing location of selected rivers. Blue, yellow, and green colored lines represent the selected rivers: blue - Mameyes (non-urban); yellow Río Piedras (urban without a dam); green - La Plata (urban with a dam). 
Citation: Ortiz-Colón Al, Piñero-Santiago LE, Rivera NM, Sosa MA (2016) Assessment of Concentrations of Heavy Metals and Phthalates in Two Urban Rivers of the Northeast of Puerto Rico. J Environ Anal Toxicol 6: 353. doi:10.4172/2161-0525.1000353

comparisons. Results were presented as mean \pm of 6-9 determinations from 2 to 3 experiments where $\mathrm{p} \leq 0.05$ was considered significant. GraphPad Prism software version 6.0 (GraphPad Software, Inc., California, USA) was used for this statistical analysis.

\section{Results}

\section{Sampling locations}

Three rivers that flow towards the Northeastern coast of Puerto Rico were selected on the basis of the desired characteristics regarding urbanism, length and elevation. These rivers are the Mameyes, Río Piedras, and La Plata (Figure 1).

Table 1: Most common phthalates available commercially. *Dimethyl phthalate (DMP) ${ }^{*} \mathrm{Di}(2$-ethylhexyl) phthalate (DEHP) *Dimethyl terephthalate (DMT) *Dibutyl phthalate (DBP) Di-n-octyl phthalate

*Butyl benzyl phthalate (BBP) Diethyl phthalate

*Diisonyl phthalate (DnOP)

Mono-2-ethylhexyl phthalate Mono-n-butyl phthalate 2-ethylhexanoic acid
The Mameyes River, selected as the non-urban reference site, is located in the municipality of Río Grande, Puerto Rico (Figure 2). The Mameyes has a continuous water flow, no dam and is within a rural area, with minimal anthropogenic influence because it is part of a biosphere reserve $[56,57]$. Sampling was conducted at its midpoint and a lower reach point near the river's exit to sea, just before the estuarine waters. It was not possible to sample from the upper reach of this river because it is found within the US Federal Reserve area of the rainforest. The midpoint of the river is located in latitude $18^{\circ} 21^{\prime} 41.62^{\prime \prime}$ North, longitude $65^{\circ} 46^{\prime} 7.58^{\prime \prime}$ West, at an elevation of 12 meters and a depth of 23.3". The access to this point was along Road 191 towards the El Yunque Rainforest, which runs parallel to the river. The chosen lower reach was at latitude $18^{\circ} 21^{\prime} 53.14^{\prime \prime}$ North, longitude $65^{\circ} 46^{\prime} 11.42^{\prime \prime}$ West, at an elevation of 10 meters and a depth of 15.7". This point was farther from the road, near a water pumping station of the Aqueducts and Sewer Authority of Puerto Rico.

Two rivers were selected as examples of urban rivers, the Río Piedras and La Plata. The Río Piedras River is located in the capital city of San Juan, Puerto Rico (Figure 2). This river has a continuous stream and no dam. The selected sampling point near its upper reach was located at latitude $18^{\circ} 20^{\prime} 38.23^{\prime}$ North, longitude $66^{\circ} 4^{\prime} 13.18^{\prime \prime}$ West, at an elevation of 69 meters and a depth of $16.3^{\prime \prime}$, right next to a shopping mall. The river's midpoint is at latitude $18^{\circ} 21^{\prime} 59.82^{\prime}$ North, longitude $66^{\circ} 03^{\prime} 48.25^{\prime \prime}$ 'West, at an elevation of 30 meters and a depth of $7.7^{\prime \prime}$. This sampling point was next to a very busy and crowded avenue, with

\section{Mameyes River}

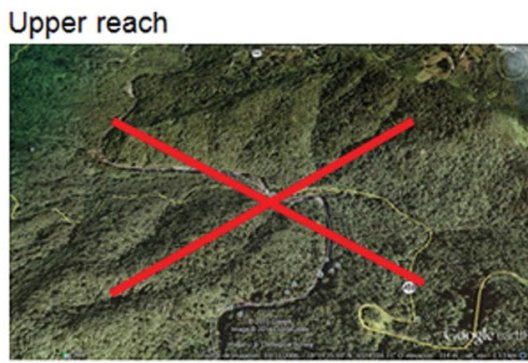

Mid-point

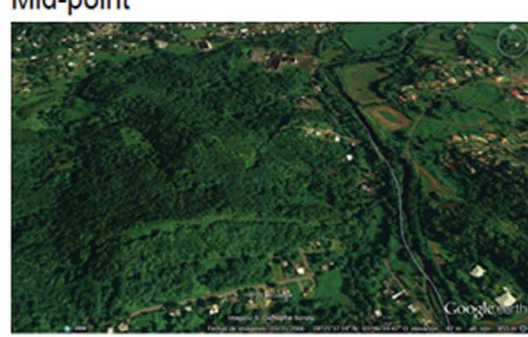

Lower reach

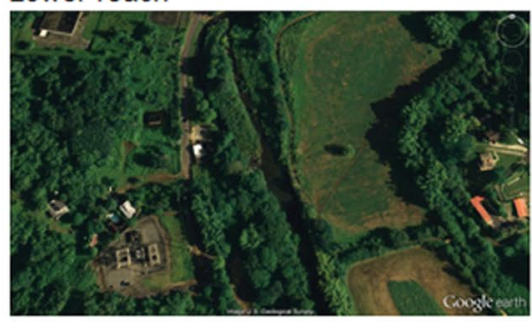

Rio Piedras River

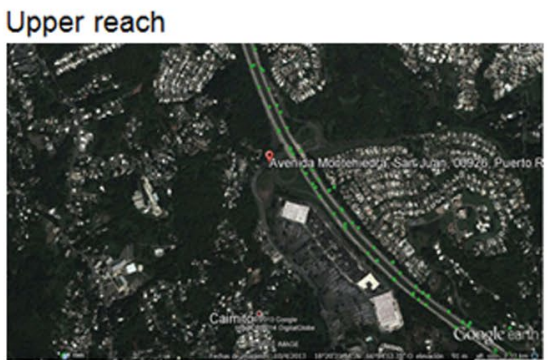

Mid-point

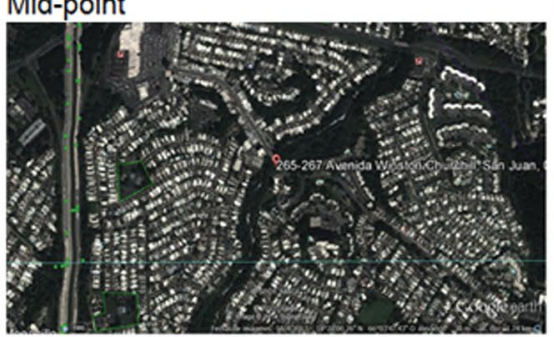

Lower reach

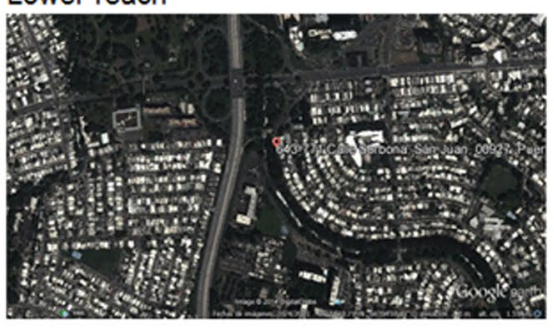

La Plata River

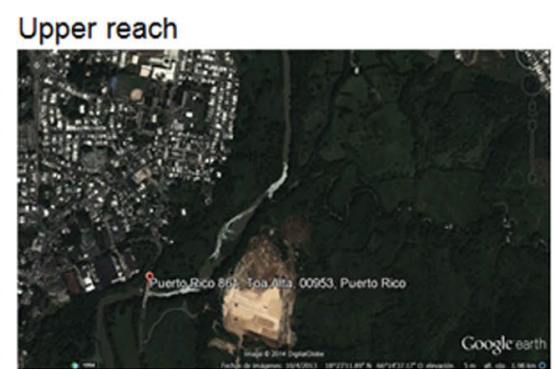

Mid-point
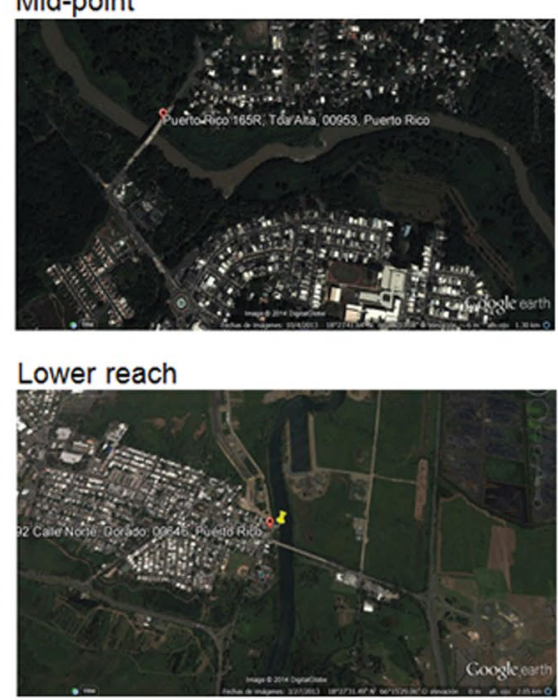

Figure 2: Satellite (Google Maps) images of the river sampling sites, illustrating the relative levels of urbanism at each. (Red X indicates that sampling was not possible at the upper reach of the Mameyes River because it corresponded to the interior to the Federal Reserve area). 
Citation: Ortiz-Colón Al, Piñero-Santiago LE, Rivera NM, Sosa MA (2016) Assessment of Concentrations of Heavy Metals and Phthalates in Two Urban Rivers of the Northeast of Puerto Rico. J Environ Anal Toxicol 6: 353. doi:10.4172/2161-0525.1000353

Page 5 of 10

Table 2: Physicochemical parameters of surface water samples obtained in a non-urban and two urban rivers on the northeast of Puerto Rico during the 2013 rainy season

\begin{tabular}{|c|c|c|c|c|c|c|c|c|c|c|c|c|}
\hline \multirow[t]{2}{*}{ Parameters } & \multicolumn{3}{|c|}{ Mameyes (NU) } & \multirow[b]{2}{*}{ Mean } & \multicolumn{3}{|c|}{ Río Piedras (U) } & \multirow[b]{2}{*}{ Mean } & \multicolumn{3}{|c|}{ La Plata (U) } & \multirow[b]{2}{*}{ Mean } \\
\hline & Upper & Mid & Lower & & Upper & Mid & Lower & & Upper & Mid & Lower & \\
\hline $\mathrm{pH}$ & NM & 7.60 & 7.70 & $7.65 \pm 0.07$ & 7.99 & 8.16 & 8.08 & $8.08 \pm 0.09^{* *}$ & 7.47 & 7.55 & 7.39 & $7.47 \pm 0.08$ \\
\hline Temperature & NM & 25.5 & 26.7 & $26.1 \pm 0.08$ & 27.2 & 27.8 & 31.3 & $28.8 \pm 2.2$ & 29.4 & 30.1 & 27.8 & $29.1 \pm 1.2$ \\
\hline Dissolved Oxygen & NM & 8.22 & 8.03 & $8.13 \pm 0.13$ & 7.36 & 7.92 & 9.15 & $8.14 \pm 0.92$ & 6.00 & 6.03 & 5.00 & $5.68 \pm 0.59^{*}$ \\
\hline
\end{tabular}

Temperature values of non-urban and urban rivers were not different statistically $(p=0.1321)$. Alkaline $p H$ at the Río Piedras river (U) was significantly different when compared with $\mathrm{pH}$ values at Mameyes $(\mathrm{NU})$ and La Plata $(\mathrm{U})\left(\mathrm{p}=0.0007^{* *}\right)$. A multiple comparison test for dissolved oxygen resulted in significant reduction of $\mathrm{DO}$ in La Plata $(U)$ when compared with DO measurements at the Mameyes (NU) and Río Piedras (U) rivers ( $p=0.0126)$. NU: non-urban river; $U$ : urban river; NM: not measured; temperature is in ${ }^{\circ} \mathrm{C}$, and dissolved oxygen is expressed as $\mathrm{mg} / \mathrm{L}$.

Table 3: Mean concentrations of heavy metals in surface water samples obtained from a non-urban and two urban rivers of Puerto Rico's northeastern region, during the 2013 rainy season.

\begin{tabular}{|c|c|c|c|c|c|c|c|c|c|c|}
\hline \multirow{2}{*}{ Metal } & \multirow[b]{2}{*}{$\begin{array}{c}\text { EPA } \\
\text { (MCL) } \\
\text { ppb }\end{array}$} & \multicolumn{3}{|c|}{ Mameyes(NU) } & \multicolumn{3}{|c|}{ Río Piedras (U) } & \multicolumn{3}{|c|}{ La Plata (U) } \\
\hline & & Upper Reach & Mid- Point & Lower Reach & Upper Reach & Mid- Point & Lower Reach & Upper Reach & Mid -Point & Lower Reach \\
\hline $\mathrm{Ag}$ & $* 100$ & NM & $<0.021$ & $0.046 \pm 0.044$ & $<0.021$ & $<0.021$ & $<0.021$ & $<0.021$ & $<0.021$ & $<0.021$ \\
\hline As & 10 & NM & $<0.150$ & $<0.150$ & $0.737 \pm 0.063$ & $0.563 \pm 0.158$ & $0.928 \pm 0.024$ & $1.177 \pm 0.688$ & $0.796 \pm 0.130$ & $1.717 \pm 0.791$ \\
\hline $\mathrm{Ba}$ & 2,000 & NM & $45.433 \pm 1.069$ & $42.233 \pm 0.764$ & $107.667 \pm 1.528$ & $102.633 \pm 3.564$ & $105.333 \pm 0.577$ & $67.900 \pm 2.138$ & $60.667 \pm 6.183$ & $66.767 \pm 1.079$ \\
\hline $\mathrm{Be}$ & 4 & NM & $<0.027$ & $0.056 \pm 0.050$ & $0.031 \pm 0.007$ & $<0.027$ & $<0.027$ & $<0.027$ & $<0.027$ & $<0.027$ \\
\hline $\mathrm{Cd}$ & 5 & NM & $0.429 \pm 0.033$ & $0.409 \pm 0.075$ & $0.421 \pm 0.049$ & $0.503 \pm 0.002$ & $0.508 \pm 0.025$ & $0.233 \pm 0.065$ & $0.348 \pm 0.026$ & $0.439 \pm 0.036$ \\
\hline $\mathrm{Cr}$ & 100 & NM & $1.843 \pm 0.064$ & $1.893 \pm 0.076$ & $1.927 \pm 0.055$ & $1.717 \pm 0.071$ & $1.663 \pm 0.091$ & $2.023 \pm 0.546$ & $1.747 \pm 0.183$ & $2.203 \pm 0.099$ \\
\hline $\mathrm{Cu}$ & 1,300 & NM & $4.267 \pm 0.356$ & $3.640 \pm 1.520$ & $4.550 \pm 0.537$ & $3.970 \pm 0.640$ & $3.537 \pm 0.522$ & $3.950 \pm 0.837$ & $2.747 \pm 0.283$ & $5.100 \pm 2.489$ \\
\hline $\mathrm{Mn}$ & * 50 & NM & $5.387 \pm 0.025$ & $10.900 \pm 0.436$ & $43.267 \pm 0.666$ & $40.333 \pm 1.102$ & $32.400 \pm 0.917$ & $188.667 \pm 4.509$ & $207.333 \pm 12.503$ & $188.333 \pm 5.508$ \\
\hline $\mathrm{Ni}$ & **100 & NM & $3.183 \pm 0.660$ & $2.513 \pm 1.300$ & $2.567 \pm 0.125$ & $2.500 \pm 0.092$ & $2.643 \pm 0.201$ & $3.393 \pm 1.171$ & $1.993 \pm 0.176$ & $4.360 \pm 1.948$ \\
\hline $\mathrm{Pb}$ & 15 & NM & $0.261 \pm 0.103$ & $0.213 \pm 0.144$ & $<0.130$ & $<0.130$ & $<0.130$ & $<0.130$ & $<0.130$ & $0.276 \pm 0.253$ \\
\hline $\mathrm{Sb}$ & 6 & NM & $<0.047$ & $0.069 \pm 0.038$ & $0.121 \pm 0.002$ & $0.101 \pm 0.002$ & $0.110 \pm 0.003$ & $0.125 \pm 0.025$ & $0.088 \pm 0.005$ & $0.106 \pm 0.012$ \\
\hline Se & 50 & NM & $0.393 \pm 0.045$ & $<0.360$ & $0.417 \pm 0.010$ & $0.425 \pm 0.059$ & $0.583 \pm 0.057$ & $1.740 \pm 2.252$ & $0.504 \pm 0.193$ & $3.210 \pm 2.475$ \\
\hline $\mathrm{TI}$ & 2 & NM & $<0.020$ & $<0.020$ & $<0.020$ & $<0.020$ & $<0.020$ & $<0.020$ & $<0.020$ & $<0.020$ \\
\hline $\mathrm{Zn}$ & *5,000 & NM & $9.733 \pm 0.095$ & $5.137 \pm 2.662$ & $<3.600$ & $<3.600$ & $<3.600$ & $4.773 \pm 1.299$ & $<3.600$ & $7.830 \pm 3.948$ \\
\hline
\end{tabular}

Mean values \pm standard deviation; MCL: Maximum Contaminant Level allowed in drinking water by the Environmental Protection Agency (EPA, 2009); ${ }^{M a x i m u m ~ s e c o n d a r y ~}$ levels allowed in drinking water (EPA, 2009); ${ }^{* \star D}$ Determined by State of California; NU: non-urban river; U: urban river; ppb: parts per billion; NM: no measured.

Table 4: Mean concentrations of heavy metals expressed as \% of Maximum Contaminant Levels (MCL) allowed in drinking water in surface water samples obtained from a non-urban and two urban rivers of Puerto Rico's northeastern region, during the 2013 rainy season.

\begin{tabular}{|c|c|c|c|c|c|c|c|c|c|c|}
\hline \multirow{2}{*}{ Metal } & \multirow[b]{2}{*}{$\begin{array}{c}\text { EPA } \\
\text { (MCL) } \\
\text { ppb }\end{array}$} & \multicolumn{3}{|c|}{ Mameyes(NU) } & \multicolumn{3}{|c|}{ Río Piedras (U) } & \multicolumn{3}{|c|}{ La Plata (U) } \\
\hline & & Upper Reach & Mid- Point & Lower Reach & Upper Reach & Mid- Point & Lower Reach & Upper Reach & Mid -Point & Lower Reach \\
\hline $\mathrm{Ag}$ & * 100 & NM & 0 & 0 & 0 & 0 & 0 & 0 & 0 & 0 \\
\hline As & 10 & NM & 2 & 2 & 7 & 6 & 9 & 12 & 8 & 17 \\
\hline $\mathrm{Ba}$ & 2,000 & NM & 2 & 2 & 5 & 5 & 5 & 3 & 3 & 3 \\
\hline $\mathrm{Be}$ & 4 & NM & 1 & 1 & 1 & 1 & 1 & 1 & 1 & 1 \\
\hline $\mathrm{Cd}$ & 5 & NM & 9 & 8 & 8 & 10 & 10 & 5 & 7 & 9 \\
\hline $\mathrm{Cr}$ & 100 & NM & 2 & 2 & 2 & 2 & 2 & 2 & 2 & 2 \\
\hline $\mathrm{Cu}$ & 1,300 & NM & 0 & 0 & 0 & 0 & 0 & 0 & 0 & 0 \\
\hline $\mathrm{Mn}$ & *50 & NM & 11 & 22 & 87 & 81 & 65 & 377 & 415 & 377 \\
\hline $\mathrm{Ni}$ & $* * 100$ & NM & 6 & 5 & 5 & 5 & 5 & 7 & 4 & 9 \\
\hline $\mathrm{Pb}$ & 15 & NM & 2 & 1 & 1 & 1 & 1 & 1 & 1 & 2 \\
\hline $\mathrm{Sb}$ & 6 & NM & 1 & 1 & 2 & 2 & 2 & 2 & 1 & 2 \\
\hline $\mathrm{Se}$ & 50 & NM & 1 & 1 & 1 & 1 & 1 & 3 & 1 & 6 \\
\hline $\mathrm{TI}$ & 2 & NM & 10 & 10 & 10 & 10 & 10 & 10 & 10 & 10 \\
\hline $\mathrm{Zn}$ & ${ }^{*} 5,000$ & NM & 0 & 0 & 0 & 0 & 0 & 0 & 0 & 0 \\
\hline
\end{tabular}

$\%$ of MCL. MCL: Maximum Contaminant Level allowed in drinking water by the Environmental Protection Agency (EPA, 2009). *Maximum secondary levels allowed in drinking water (EPA); **Determined by State of California; NU: non-urban river; U: urban river; ppb: parts per billion; NM: no measured 
various food establishments, clothing stores, schools, pharmacies, and residences nearby, with sewer runoffs from the area draining towards the river. The selected lower reach sampling point was at latitude $18^{\circ} 24^{\prime} 19.67^{\prime \prime}$ North, longitude $66^{\circ} 04^{\prime} 08.46^{\prime \prime}$ 'West, at an elevation of 3 meters and a depth of $10^{\prime \prime}$. This point was near a major expressway and several exits to large avenues in the city's metropolitan area.

The La Plata River is located in the municipalities of Dorado and Toa Alta, and has a regulated flow and a dam reservoir (Figure 2). The selected sampling point near its upper reach was located at latitude $18^{\circ} 22^{\prime} 59.29^{\prime \prime}$ North, longitude $66^{\circ} 14^{\prime} 56.59^{\prime \prime}$ West, at an elevation of 8 meters and a depth of 12 ". Crossing over the river is a tall bridge with two eastbound and two westbound lanes. The river's midpoint is at latitude $18^{\circ} 23^{\prime} 43.94^{\prime \prime}$ North, longitude $66^{\circ} 15^{\prime} 15.44^{\prime \prime}$ West, at an elevation of 4 meters and a depth of 58.3". This sampling site was near a gas station, a garden center and some houses. The selected lower reach sampling point, located at the entrance to Dorado's town and also crossed by a bridge that gives entry to the town's center, was at latitude $18^{\circ} 27^{\prime} 29.86^{\prime \prime}$ North, longitude $66^{\circ} 15^{\prime} 30.44^{\prime \prime}$ West, at an elevation of 1 meter and a depth of 24.5 ".

\section{Physicochemical parameters}

Measures of the physicochemical parameters of $\mathrm{pH}$, temperature, and dissolved oxygen at the three rivers at the time of sampling are shown in Table 2 . These three parameters did not differ significantly along the length of each river. The $\mathrm{pH}$ values at the selected sampling points of the three rivers ranged from 7.39 at La Plata's low reach to 8.16 at the Rio Piedra's midpoint. The mean $\mathrm{pH}$ at Mameyes and La Plata were near neutral, while that at the Río Piedras was significantly more alkaline $(p=0.0007)$. The temperatures at the three rivers, which ranged from $25.5^{\circ} \mathrm{C}$ at the Mameye's midpoint to $31.3^{\circ} \mathrm{C}$ at the Río Piedras lower reach, did not differ significantly. The largest differences amongst the three rivers were observed in the parameter of dissolved oxygen, which ranged from 5.00 at La Plata's lower reach to $9.15 \mathrm{mg} / \mathrm{L}$ at Río Piedras lower reach. The mean dissolved oxygen at La Plata was significantly lower than those of the Mameyes and the Río Piedras rivers.

\section{Heavy metals in superficial water samples}

The mean concentration values at each collection point at the time of sampling of the group of fourteen heavy metals analyzed in the three rivers are shown in Table 3. Mean overall values (averages of collection sites) for each river, expressed as percentage of the maximum contaminant levels (MCL) established by the United States Environmental Protection Agency (EPA) for drinking water, are shown in Table 4.

Concentration ranges, classified as $\leq 1 \%, 1-10 \%, 10-25 \%, 25-100 \%$, and $>100 \%$ MCL, were similar amongst each collection point of each river, except in the case of Río La Plata, where concentrations for As were found at different \% MCL ranges in one collection point.

At the Mameyes, the non-urban reference river, $\mathrm{Ag}, \mathrm{Be}, \mathrm{Cu}$, $\mathrm{Se}$, and $\mathrm{Zn}$ were found at or below $1 \% \mathrm{MCL}$, while $\mathrm{As}, \mathrm{Ba}, \mathrm{Cd}, \mathrm{Cr}, \mathrm{Ni}, \mathrm{Pb}, \mathrm{Tl}$ and $S b$ were in the range of $1-10 \% \mathrm{MCL}$, and $M n$ was found in the range of 10-25\% MCL. At the Río Piedras, an urban river with no dams, the range of \% MCL at which these metals were observed were similar to those found for the Mameyes, with the only difference that $P b$ was found at a lower range (below $1 \% \mathrm{MCL}$ ) and $M n$ was found at a higher range (25-100\% MCL). At the upper and midpoint reaches of La Plata, an urban river with a dam, $P b$ was also found in a range different to that at Mameyes (below $1 \% \mathrm{MCL}$ ), while Se reached the 1-10\% MCL range, and As reached that of $10-25 \%$ at the upper reach (as it also did at the lower reach). Manganese $(\mathrm{Mn})$ at the three collection sites at La Plata was found at amounts that more than tripled or quadrupled the EPA's $\mathrm{MCL}$, these being the only sites where a heavy metal was observed to exceed the EPA's maximum contaminant levels for drinking water.

Significant differences between the non-urban and urban rivers were observed in the concentrations of $A s, B a, C d, M n, S b$, and $Z n$ (Figure 3). The concentrations of $A s, B a, M n$, and $S b$ were higher in both urban rivers, whereas the concentration of $C d$ was higher in the urban river without a dam but not the one with a dam, and the concentration of $Z n$ was lower in both urban rivers. Significant differences between the two urban rivers, one with a dam (La Plata) and the other without (Río Piedras), were observed in the concentrations of $A s, B a, C d$ and $M n$ (Figure 3). The concentrations of $A s$ and $M n$ were higher at La Plata, the river with a dam, while those of $B a$ and $C d$ were higher at Río Piedras, the river without a dam. Significant differences between different collection sites within the same river were observed only for $C d$ and $M n$ at La Plata, where $C d$ concentration increased at a site closer to the river's exit toward the sea, while the highest concentration of $M n$ was found at the midpoint of the river, having similar lower concentrations at the upper and lower reaches (Figure 3).

\section{Phthalates in superficial water samples}

We found that of the six phthalates we tested for, selected as described above in the Materials and Methods section, only dibutyl phthalate (DBP) was found in concentrations that could be reliably detected by our GC-MS instrument. This particular phthalate was found only in samples from the La Plata River, at concentrations of 6, 8 and $3 \mu \mathrm{g} / \mathrm{L}$ (ppb), in the upper, midpoint, and lower reaches of the river, respectively.

\section{Discussion}

The increase of the population and the development in Latin American countries and the Caribbean has caused a rapid urban growth, where many inhabitants have migrated and concentrated in urban zones. Puerto Rico is a densely-populated small tropical island where urban development along coastal metropolitan areas has consistently increased for the past 70 years, and where $40 \%$ of its land has been experiencing significant urban sprawl for the past 40 years [5,58-68]. As more people have moved from rural areas to urban zones, socio-demographic changes linked to a shift from agriculture to an industrial basis for the island's economy, anthropogenic activities have become one of the main sources of pollution for nearby water systems. These activities, which include construction of housing, streets and highways, increased automobile traffic, use of septic tanks, and illegal dumping of waste from homes and businesses, have led to the emergence of contaminants such as esters, phthalates, derivatives of petroleum based fuel, and metals in many of the island's varied ecosystems, including the rainforest, dry forest, beaches, cave systems, the karst, coast waters, lakes and rivers. Among these ecosystems, rivers are one of the most important, being a primary source of water considered safe for human consumption and use. Rivers are also the natural habitat of a wide variety of plants and animals, many of which are used as food or are part of the human food chain. Thus, resources from freshwater ecosystems directly contribute to the survival of the Puertorrican population and attract many people to settle on or near river banks. However, contamination of rivers due to increases in urbanization can in turn negatively impact the health of humans and other animal species. 

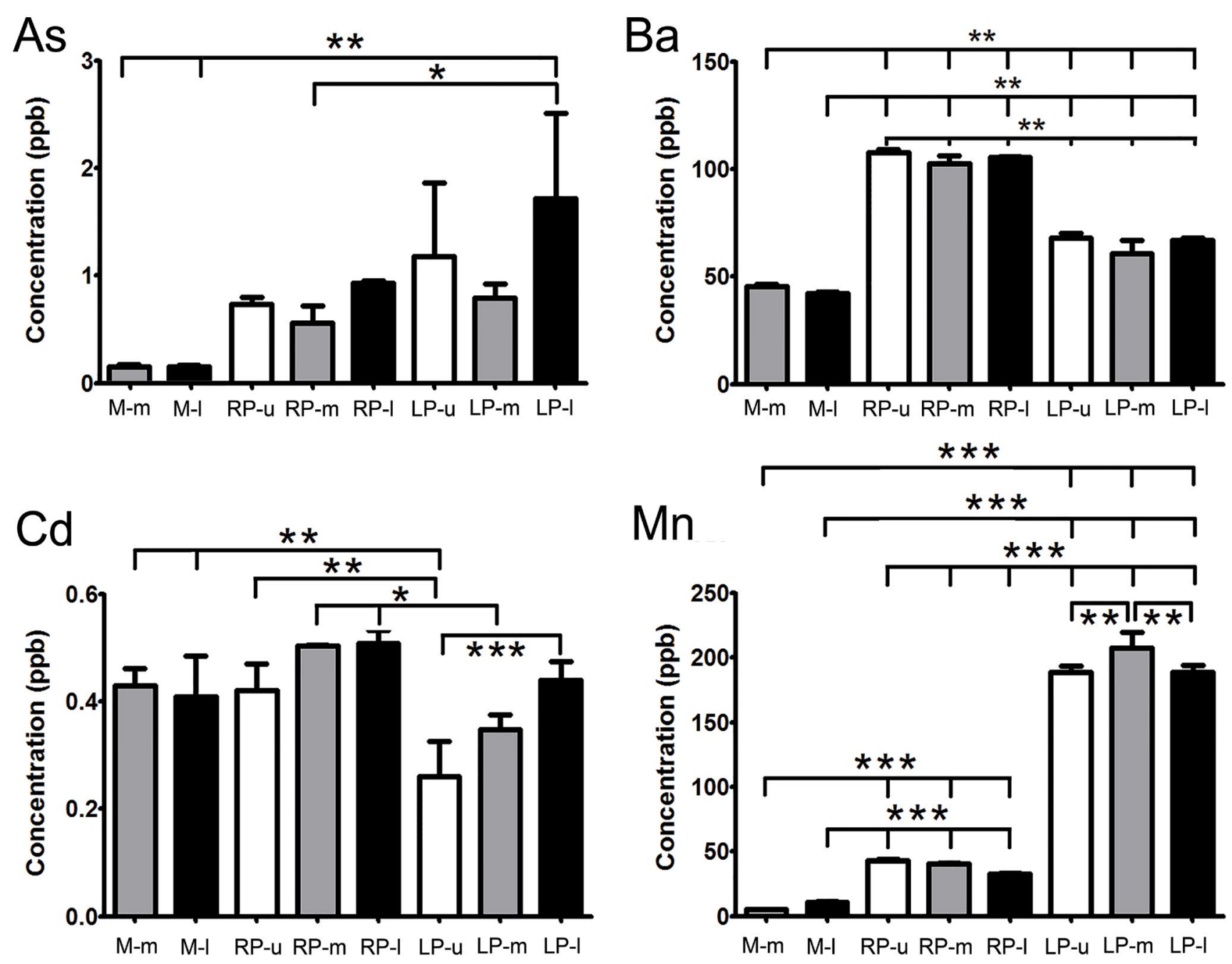

$\mathrm{Sb}$
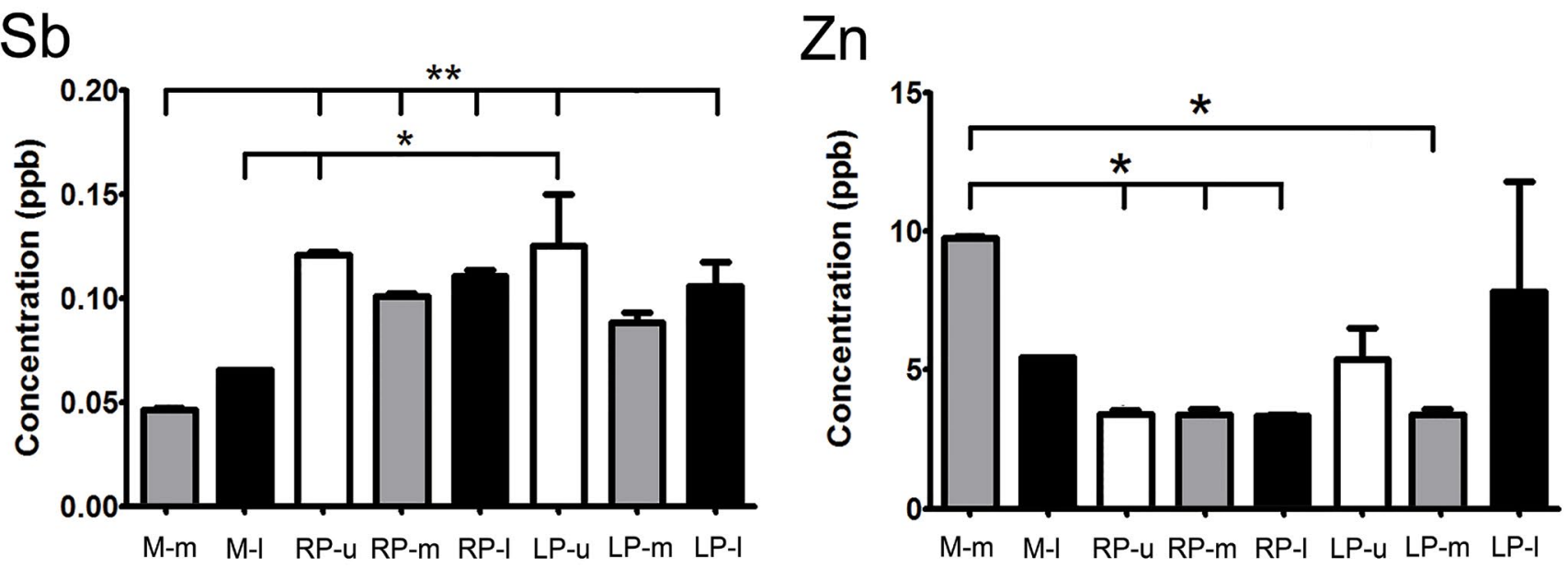

Figure 3: Comparison of heavy metal concentrations that were found to differ significantly amongst non-urban and urban rivers at the northeast of Puerto Rico during

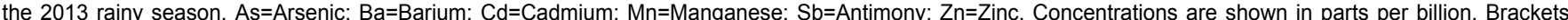
indicate comparisons where differences were significant $\left({ }^{*} \mathrm{p}<0.05,{ }^{* *} \mathrm{p}<0.01,{ }^{* *} \mathrm{p}<0.001\right)$. M=Mameyes river; RP=Río Piedras river; LP=La Plata river; $\mathrm{u}=\mathrm{upper}$ reach; m=midpoint; l=lower reach. 
Heavy metals and phthalates, as emergent pollutants, are of global concern due to the bioaccumulation, persistence and impact on ecosystems. It is known that inorganic compounds, including heavy metals, can have multiple toxic effects that negatively impact the function of the kidneys, lungs, heart, bones, skin, and various other target organs, including the nervous system [20]. There is also growing evidence that some phthalates, which can pass the blood brain barrier in mammals, may be linked with neural cellular and developmental deficits in rodents [69-71] and humans [72]. In Puerto Rico, where the incidence of premature births is amongst the highest in the world [73], results from longitudinal studies to monitor concentrations of contaminants found in urine among pregnant women indicate that certain urine phthalate metabolites are higher in Puerto Rico than those measured in women of reproductive age from the general US population [74]. Other reports link urinary phthalate metabolites in pregnant women in Puerto Rico with biomarkers of increased inflammation and oxidative stress [75]. Our research group has conducted experiments, as part of studies at the Puerto Rico Center for Environmental Neuroscience, where preliminary results indicate that short term exposure to low concentrations of phthalates may have an effect on dominant and submissive behaviors, as well as on general patterns of locomotive activity in freshwater crustaceans.

Regarding water pollution in rivers of Puerto Rico, the US Geological Survey, the agency in charge of monitoring water quality, has not issued reports on levels of specific contaminants such as heavy metals, plastics, or pharmaceutical products during the past 10 years. Very few studies on the impact of urbanism on contamination and the resulting degradation of river ecosystems have been conducted in tropical regions, particularly in the Caribbean $[8,55]$. Only last year was an initial study published on the impact of urbanism on water quality of Cuba's Almendares River [76]. In Puerto Rico, the single environmental study conducted by a local investigator during the past decade [8] showed that the Río Piedras river has high concentrations of phosphates, potassium and magnesium, increments that were related with the increase in urbanization close to the river. However, little is known about other emergent pollutants, such as metals and phthalates, which are presently the focus of attention in Puerto Rico of various studies on potential effects on reproductive, developmental, and nervous system function in both humans and animals

Our study focusing on the correlation between river contamination and urbanism shows that concentrations of heavy metals arsenic, barium, cadmium, manganese, and antimony are higher in urban rivers such as La Plata and the Río Piedras, compared to amounts found in a non-urban river, the Mameyes. The amounts of heavy metals obtained from superficial water samples were relatively low as compared with those reported by the US EPA as safe for drinking purposes, with only manganese being significantly (four times) higher than the allowed limit (US EPA: $5 \mu \mathrm{g} / \mathrm{l}$ ).

In addition, dibutyl phthalate, a plasticizer and an emergent pollutant, was found at La Plata, but not the Río Piedras. Concentrations at La Plata ranged from $3 \mathrm{ppb}$ at the river's lower reach, to $6 \mathrm{ppb}$ at the upper reach, and $8 \mathrm{ppb}$ in the midpoint, the latter amount being above the EPA's MCL for drinking water of $6 \mathrm{ppb}$. The difference between these two urban rivers is the presence of a dam in La Plata, located near the selected upper reach. The fact that the flow of the Río Piedras is not limited nor affected by any dam may contribute to a lower level of accumulation of certain contaminants, such as phthalates.

It is important to point out that this study was conducted during the rainy season of 2013; therefore, it is possible that high flow rates and disturbance in the river due to frequent rainfall could have led to re-suspension and downstream movement of pollutants into the water column. Thus, sampling of these rivers during the dry season will be very useful to compare outcomes and establish potential differences with the amounts of these emergent contaminants observed during the rainy season.

\section{Conclusion}

Inductively Coupled Plasma and Gas Chromatography Mass Spectrometry were used to measure amounts of heavy metals and phthalates, respectively, in superficial water of three rivers of Puerto Rico: Mameyes (non-urban), Río Piedras (urban river without a dam), and La Plata (urban river with a dam). The urban rivers had significantly higher concentrations of heavy metals arsenic, barium, cadmium, manganese, and antimony, as compared with the reference non-urban river. Zinc at urban rivers was significantly lower than at the non-urban river. Manganese was the only metal found in concentrations higher than the maximum contaminant limits established for drinking water by the United States' EPA. Of six phthalates amenable to measurement with the chosen protocol and instrumentation, only dibutyl phthalate was detected, only in the La Plata River, and at concentrations ranging from 3 to 8 parts-per-billion. These findings suggest that urbanism close to rivers of Puerto Rico is likely having an impact on water quality and thus further study to identify the potential sources, as well as the inclusion of these emergent contaminants on the list of chemicals regularly monitored by government agencies is justified.

We should be aware of the potential danger for these rivers of increasing concentrations of these emergent contaminants on both aquatic wildlife and humans experiencing prolonged or persistent exposure. Of particular concern is the high level of $\mathrm{Mn}$ observed in La Plata, since it is known that this metal can cross both the bloodbrain barrier as well as the placenta during pregnancy, and at high concentrations can affect nervous system function and behavior [77] Therefore, it is recommended that the relative high concentration of $\mathrm{Mn}$ in La Plata watershed be further monitored to assess its source, mobility, levels, bioavailability and persistence.

\section{Acknowledgements}

The authors wish to thank Lic. Maritza Merced and Mr. Jorge Casado fo their assistance with the analysis of heavy metals in the facilities of the Regional Laboratory of the Water and Sewer Authority of Caguas, Puerto Rico, as well as the support and collaboration of Dr. José Díaz Piñero, Interim Chair, and Prof. Jorge Castillo, of the Department of Chemistry at the Humacao Campus of the University of Puerto Rico, in giving us access to their facilities and instrumentation for the analysis of phthalates.

This research project is part of Ana I. Ortiz-Colón's doctoral thesis dissertation. The project was supported by grants from the National Science Foundation (NSF) HRD-1137725 CREST, the National Institutes of Health (NIH) MBRS SCORE SC3GM084763, and NIH MBRS-RISE 2R25-GM061838-13.

\section{References}

1. United Nations (1998) World urbanization prospects. The 1996 revision Estimates and projections of urban and rural. Upper Columbia River Work Plan for the Remedial Investigation and Feasibility Study USEPA. p: 2001.

2. Montgomery MR (2008) The urban transformation of the developing world Science 319: 761-764

3. Population Estimates and Projections (2016) World Bank Group [data worldbank.org/data-catalog/population-projection-tables]

4. United States Census Bureau (2010) Resident Population Data, [www.census gov/2010census/data/apportionment-dens-text.php]

5. Martinuzzi S, Gould W, Ramos Gonzalez OM (2007) Land development, land use, and urban sprawl in Puerto Rico integrating remote sensing and population 
Citation: Ortiz-Colón Al, Piñero-Santiago LE, Rivera NM, Sosa MA (2016) Assessment of Concentrations of Heavy Metals and Phthalates in Two Urban Rivers of the Northeast of Puerto Rico. J Environ Anal Toxicol 6: 353. doi:10.4172/2161-0525.1000353

census data. Landsc Urban Plan 79: 288-297.

6. Comisión Económica para América Latina y el Caribe (1983) El agua y la expansión urbana en zonas áridas. Santiago de Chile.

7. Pérez EG, Shaner W (1996) Oficina Regional para América Latina y el Caribe, Santiago de Chile. Manejo cuencas. Una orientación hacia los países en Desarro. Organ las Nac Unidas para la Agric. y la Aliment.

8. Ramírez A, De Jesús-Crespo R, Martinó-Cardona DM, Martínez-Rivera N Burgos-Caraballo S (2009) Urban streams in Puerto Rico: what can we learn from the tropics. J North Am Benthol Soc 28: 1070-1079.

9. Vukovic Z, Markovic L, Radenkovic M, Vukovic D, Stankovic S (2011) Heavy metal and bacterial pollution of the Sava River in Serbia. Arh Hig Rada Toksikol 62: $11-16$.

10. Ayotunde EO, Offem BO, Ada FB (2012) Heavy metal profile of water, sediment and freshwater cat fish, Chrysichthys nigrodigitatus (Siluriformes: Bagridae), of Cross River, Nigeria. Rev Biol Trop 60: 1289-1301.

11. Eneji IS, Sha'Ato R, Annune PA (2012) An assessment of heavy metals loading in River Benue in the Makurdi metropolitan area in Central Nigeria. Environ Monit Assess 184: 201-207.

12. Lin J, Fu C, Zhang X, Xie K, Yu Z (2012) Heavy metal contamination in the water-level fluctuating zone of the Yangtze River within Wanzhou Section, China. Biol Trace Elem Res 145: 268-272.

13. Malhat FM, Nasr I (2012) Metals in water from the River Nile tributaries in Egypt. Bull Environ Contam Toxicol 88: 594-596.

14. Saarinen TS, Kløve B (2012) Past and future seasonal variation in pH and metal concentrations in runoff from river basins on acid sulphate soils in Western Finland. J Environ Sci Heal Part A Toxic/Hazardous Subst Environ Eng 47: 1614-1625.

15. Chanpiwat $P$, Sthiannopkao $S$ (2014) Status of metal levels and their potentia sources of contamination in Southeast Asian rivers. Environ Sci Pollut Res Int 21: $220-233$.

16. Da Silva Alves RI, De Oliveira Cardoso O, De Abreu Tonani KA, Julião FC Trevilato TM, et al. (2013) Water quality of the Ribeirão Preto Stream, a watercourse under anthropogenic influence in the southeast of Brazil. Environ Monit Assess 185: 1151-1161.

17. Nagy AS, Szabó J, Vass I (2013) Trace metal and metalloid levels in surface water of Marcal River before and after the Ajka red mud spill, Hungary. Environ Sci Pollut Res Int 20: 7603-7614.

18. Correa M (1987) Physiological effects of metal toxicity on the tropical freshwater shrimp Microbrachium carcinus (Linneo, 1758). Environ Pollut 45: 149-155.

19. Adejare LI, James BK, Shelle R (2011) Hidrochemistry and levels of some heavy metals in samples of Ibeshe, Lagos Lagoon Complex, Nigeria. J Am Sci 7: 625-632.

20. Järup L (2003) Hazards of heavy metal contamination. Br Med Bull 68: 167-

21. Miller JR, Hudson-Edwards K, Lechler PJ, Preston D, Macklin MG (2004) Heavy metal contamination of water, soil and produce within riverine communities of the Río Pilcomayo basin, Bolivia. Sci Total Environ 320: 189-209.

22. Zheng N, Wang Q, Liang Z, Zheng D (2008) Characterization of heavy metal concentrations in the sediments of three freshwater rivers in Huludao City, Northeast China. Environ Pollut 154: 135-142.

23. Yang Z, Shen Z, Gao F, Zhenwu Tang, Junfeng Niu (2009) Occurrence and possible sources of polychlorinated biphenyls in surface sediments from the Wuhan reach of the Yangtze River, China. Chemosphere 74: 1522-1530.

24. Akbulut A, Akbulut NE (2010) The study of heavy metal pollution and accumulation in water, sediment, and fish tissue in Kizilirmak River Basin in Turkey. Environ Monit Assess 167: 521-526.

25. Carafa R, Faggiano L, Real M, Munné A, Ginebreda A, et al. (2011) Water toxicity assessment and spatial pollution patterns identification in a Mediterranean River Basin District. Tools for water management and risk analysis. Sci Total Environ 409: 4269-4279.

26. Malhat $F$ (2011) Distribution of heavy metal residues in fish from the River Nile tributaries in Egypt. Bull Environ Contam Toxicol 87: 163-165.
27. Nduka JK, Orisakwe OE (2011) Water-quality issues in the Niger Delta of Nigeria: a look at heavy metal levels and some physicochemical properties. Environ Sci Pollut Res Int 18: 237-246.

28. Ruelas-Inzunza J, Green-Ruiz C, Zavala-Nevárez M, Soto-Jiménez M (2011) Biomonitoring of $\mathrm{Cd}, \mathrm{Cr}, \mathrm{Hg}$ and $\mathrm{Pb}$ in the Baluarte River basin associated to a mining area (NW Mexico). Sci Total Environ 409: 3527-3536.

29. Yi Y, Yang Z, Zhang S (2011) Ecological risk assessment of heavy metals in sediment and human health risk assessment of heavy metals in fishes in the middle and lower reaches of the Yangtze River basin. Environ Pollut 159: 2575-2585.

30. Orisakwe OE, Nduka JK, Amadi CN, Dike DO, Bede O (2012) Heavy metals health risk assessment for population via consumption of food crops and fruits in Owerri, South Eastern, Nigeria. Chem Cent J 6: 77.

31. Tao Y, Yuan Z, Xiaona H, Wei M (2012) Distribution and bioaccumulation of heavy metals in aquatic organisms of different trophic levels and potentia health risk assessment from Taihu lake, China. Ecotoxicol Environ Saf 81: 5564.

32. Playle RC, Dixon DG, Burnison K (1993) Copper and cadmium binding to fish gills: Estimates of metal-gill stability constants and modelling of metal accumulation. Can J Fish Aquat Sci 50: 2678-2687.

33. Per-Erik O, Peter K, Hogstrand C (1998) Mechanisms of heavy metal accumulation and toxicity in fish. Met Metab Aquat Environ 321-350.

34. McGeer JC, Szebedinszky C, Gordon McDonald D, Wood CM (2000) Effects of chronic sublethal exposure to waterborne $\mathrm{Cu}, \mathrm{Cd}$ or $\mathrm{Zn}$ in rainbow trout 2 : tissue specific metal accumulation. Aquat Toxicol 50: 245-256.

35. Matsuo AY, Wood CM, Val AL (2005) Effects of copper and cadmium on ion transport and gill metal binding in the Amazonian teleost tambaqui (Colossoma macropomum) in extremely soft water. Aquat Toxicol 74: 351-364.

36. Kusch RC, Krone PH, Chivers DP (2008) Chronic exposure to low concentrations of waterborne cadmium during embryonic and larval development results in the long-term hindrance of antipredator behavior in zebrafish. Environ Toxicol Chem 27: 705-710.

37. Matsuo AY, Val AL (2007) Dietary tissue cadmium accumulation in an amazonian teleost (Tambaqui, Colossoma macropomum Cuvier, 1818). Braz J Biol 67: 657-661.

38. Vardy DW, Tompsett AR, Sigurdson JL, Doering JA, Zhang X, et al. (2011) Effects of subchronic exposure of early life stages of white sturgeon (Acipenser transmontanus) to copper, cadmium, and zinc. Environ Toxicol Chem 30: 2497505

39. Hubschman JH (1967) Effects of copper on the crayfish Orconectes rusticus (Girard). Crustaceana 12: 33-42.

40. Connor PM (1972) Acute toxicity of heavy metals to some marine larvae. Mar Pollut Bull 3: 190-192.

41. Havas M (1985) Aluminum bioaccumulation and toxicity to Daphnia magna in soft water at low pH. Can J Fish Aquat Sci 42: 1741-1748.

42. Wang WX, Fisher NS (1999) Delineating metal accumulation pathways for marine invertebrates. Sci Total Environ 237-238: 459-472.

43. Rainbow PS (2002) Kenneth Mellanby Review Award. Trace metal concentrations in aquatic invertebrates: why and so what? Environ Pollut 120 497-507.

44. Revathi P, Vasanthi LA, Munuswamy N (2011) Effect of cadmium on the ovarian development in the freshwater prawn Macrobrachium rosenbergii (De Man). Ecotoxicol Environ Saf 74: 623-629.

45. Khan FR, Bury NR, Hogstrand C (2012) Copper and zinc detoxification in Gammarus pulex (L.). J Exp Biol 215: 822-832.

46. Vellinger C, Gismondi E, Felten V, Philippe Rousselle, Kahina Mehennaoui, et al. (2013) Single and combined effects of cadmium and arsenate in Gammarus pulex (Crustacea, Amphipoda): Understanding the links between physiological and behavioral responses. Aquat Toxicol 140-141: 106-116.

47. Samara F, Tsai CW, Aga DS (2006) Determination of potential sources of PCBs and PBDEs in sediments of the Niagara River. Environ Pollut 139: 489-497.

48. Totten LA, Panangadan M, Eisenreich SJ, Cavallo GJ, Fikslin TJ (2006) Direct and indirect atmospheric deposition of PCBs to the Delaware River watershed. Environ Sci Technol 40: 2171-2176. 
Citation: Ortiz-Colón Al, Piñero-Santiago LE, Rivera NM, Sosa MA (2016) Assessment of Concentrations of Heavy Metals and Phthalates in Two Urban Rivers of the Northeast of Puerto Rico. J Environ Anal Toxicol 6: 353. doi:10.4172/2161-0525.1000353

49. Davis JA, Hetzel F, Oram JJ, McKee LJ (2007) Polychlorinated biphenyls (PCBs) in San Francisco Bay. Environ Res 105: 67-86.

50. Faroon O, Jones D, de Rosa C (2000) Effects of polychlorinated biphenyls on the nervous system. Toxicol Ind Health 16: 305-333.

51. Tatsuta N, Nakai K, Murata K, Suzuki K, Iwai-Shimada M, et al. (2014) Impacts of prenatal exposures to polychlorinated biphenyls, methylmercury, and lead on intellectual ability of 42-month-old children in Japan. Environ Res 133: 321 326.

52. Abella V, Santoro A, Scotece M, Conde J, López-López V, et al. (2015) Nondioxin-like polychlorinated biphenyls (PCB 10, PCB 153 and PCB 180) induce chondrocyte cell death through multiple pathways. Toxicol Lett 234: 13-19.

53. Cousins AP, Holmgren T, Remberger M (2014) Emissions of two phthalate esters and BDE 209 to indoor air and their impact on urban air quality. Sci Total Environ 470-471: 527-35.

54. He H, Hu GJ, Sun C, Chen SL, Yang MN, et al. (2011) Trace analysis of persistent toxic substances in the main stream of Jiangsu section of the Yangtze River, China. Environ Sci Pollut Res Int 18: 638-648.

55. Dudgeon D (2000) Riverine biodiversity in Asia: A challenge for conservation biology. Hydrobiologia 418: 1-13.

56. Wadsworth FH (2006) La otra mitad de la conservación forestal. Acta Cien 20: 93-97.

57. Hamilton LS, Juvik JO, Scatena FN (1995) Tropical Montane Cloud Forests Ecological Studies 110, Springer Verlag, New York, p: 407.

58. Creed JT, Brockhoff CA, Martin TD (1994) Method 200.8 Determination of trace elements in waters and wastes by inductively coupled plasma-mass spectrometry. Environmental Monitoring Systems Laboratory, Office of Research and Development, US Environmental Protection Agency, Cincinnati, $\mathrm{OH}, \mathrm{Rev} 5$.

59. Martin TD, Creed JT, Brockhoff CA (1994) Method 200.2 Sample preparation procedure for spectrochemical determination of total recoverable elements. Environmental Monitoring Systems Laboratory, Office of Research and Development, US Environmental Protection Agency, Cincinnati, OH, Rev 2.8.

60. Marta P, Borrull F, Marcé RM, Pocurull E (2011) Analytical methods for personal-care products in environmental water. Trends Anal Chem 30: 749760.

61. Yu Y, Wu L (2011) Comparison of four extraction methods for the analysis of pharmaceuticals in wastewater. J Chromatogr A 1218: 2483-2489.

62. Karolak S, Nefau T, Bailly E, Solgadi A, Levi Y (2010) Estimation of illicit drugs consumption by wastewater analysis in Paris area (France). Forensic Sci Int 200: 153-160.

63. Bono-Blay F, Guart A, de la Fuente B, Pedemonte M, Pastor MC, et al. (2012) Survey of phthalates, alkylphenols, bisphenol $A$ and herbicides in Spanish source waters intended for bottling. Environ Sci Pollut Res Int 19: 3339-3349.
64. Li X, Zhong M, Xu S, Sun C (2006) Determination of phthalates in water samples using polyaniline-based solid-phase microextraction coupled with gas chromatography. J Chromatogr A 1135: 101-108.

65. Li BM, Yuan C, Zong ZM, Jing-pei CAO, Guang-feng LIU, et al. (2007) GC/MS Analysis of Organic Compounds in Hot Water-Extractable Fraction from Shenfu Coal. J China Univ Min Technol 17: 354-357.

66. Domínguez-Morueco N, González-Alonso S, Valcárcel Y (2014) Phthalate occurrence in rivers and tap water from central Spain. Sci Total Environ 500501: 139-46.

67. López TM, Aide TM, Thomlinson JR (2001) Urban expansion and the loss of prime agricultural lands in Puerto Rico. Ambio 30: 49-54.

68. Helmer EH (2004) Forest conservation and land development in Puerto Rico. Landscape Ecol 19: 29-40.

69. Dhanya CR, Indu AR, Deepadevi KV, Kurup PA (2003) Inhibition of membrane $\mathrm{Na}(+)-\mathrm{K}+$ Atpase of the brain, liver and RBC in rats administered di(2-ethyl hexyl) phthalate (DEHP) a plasticizer used in polyvinyl chloride (PVC) blood storage bags. Indian J Exp Biol 41: 814-820.

70. Lin CH, Tsan-Ju C, Shun-Sheng C, Chun HP, Rei-Cheng Y (2011) Activation of Trim17 by PPAR_is involved in Di(2-ethylhexyl) phthalate (DEHP)-induced apoptosis on Neuro-2a cells. Toxicol Lett 206: 245-251.

71. Smith CA, Macdonald A, Holahan MR (2011) Acute postnatal exposure to di(2 ethylhexyl) phthalate adversely impacts hippocampal development in the male rat. Neuroscience 193: 100-108.

72. Szychowski KA, Wójtowicz AK (2013) Components of plastic disrupt the function of the nervous system. Postepy Hig Med Dosw 67: 499-506.

73. March of Dimes (2015) Premature Birth Report Card, March of Dimes Foundaton, marchofdimes.org/reportcard.

74. Cantonwine DE, Cordero JF, Rivera-Gonzalez LO, Anzalota Del Toro LV Ferguson KK, et al. (2014) Urinary phthalate metabolite concentrations among pregnant women in Northern Puerto Rico: Distribution, temporal variability, and predictors. Environ Int 62: 1-11.

75. Ferguson KK, Cantonwine DE, Rivera-González LO, Loch-Caruso $R$ Mukherjee B, et al. (2014) Urinary phthalate metabolite associations with biomarkers of inflammation and oxidative stress across pregnancy in Puerto Rico. Environ Sci Technol 48: 7018-7025.

76. Santana JL, Massone CG, Valdés M, Vazquez R, Lima LA, et al. (2015) Occurrence and Source Appraisal of Polycyclic Aromatic Hydrocarbons (PAHs) in Surface Waters of the Almendares River, Cuba. Arch Environ Contam Toxicol 69: 143-152.

77. Eckenfelder WWJ (1989) Industrial Water Pollution Control. McGraw-Hill, New York, pp: 98-110. 